\title{
Analysis of Common Security Factor on Energy Industry
}

\author{
Sanghyun Park, Sangkyo Oh and Kyungho Lee \\ Center for Information Security Technologies, Korea University, Seoul, Korea \\ \{parksh1,darkapple, kevinlee\}@korea.ac.kr
}

\begin{abstract}
The energy industry has several industry group such as nuclear, thermal, hydro, gas, electricity. There are evident the common ground and differences among nuclear, thermâl, hydro, gas, electricity. The common grounds of them are originated in energy indust y group and the differences are divided from each energy control system.

At the present, the issue is not there are many papers indicated each chardcteristic of nuclear, thermal, hydro, gas, electricity but there isn't paper indicated conimon ground as a single energy industry. The other issue is that the analysisdata used to evaluate and analyze in such papers was not the specialized data but the general IT data. Wot considering the difference between general IT environment and environment of the energy group probably bring out the distortion in the analysis data.

This paper solved the problems previously indicated and presented the common ground as the energy industry and prove them thrôgh statistical analysis. To put it concretely, this paper will present the sub domains that the whole energy industry groups always carry out and prove them through statistical analysis.

The result of this paper is expected to be important data available reference to being planned and managed the policy applicable to the whole energy group by the policy maker.
\end{abstract}

Keywords: Energy Industry group, Common grounds, Common Security factor

\section{Introduction}

Energy indastry of the country is important and generally people agree and empathize for importance of energy industry. If the energy industry is important, management and evaluation of the energy ndustry should also detail and achieve effectiveness of management and evaluation. However, assessment and management for energy industry in the field is not detail and does not achieve effectiveness. Because energy industry groups are evaluated as general information security checklist not specific energy industry checklist. Such a common criteria can make the evaluation result unsuitable for each energy group. Therefore it is difficult to find the common ground of the whole energy industry group by using the basic common criteria to evaluate and analyze. Although they find the common ground, most of them are-not accurate.

For this reason, this paper evaluates the energy industry groups as specific energy industry checklist to obtain meaningful results and then analyzes to find common security factors on energy industry that is nuclear, thermal, hydro, gas, electricity and so on.

Prior to beginning this paper, the controls and survey questions suitable for each energy group are made and sent to the each groups. And then that questionnaires are gathered as a unit of individual group and compare and analyze, and we find the common security factor by checking on the controls observed in common. After that we analyze them and prove the significance as the common security factor by using statistical analysis. 
The common security factor presented in this paper is not the characteristics of the individual energy group but the characteristics of the whole energy industry. And the characteristics of the individual energy group contains the main value relevant to the industry. Through the results of this paper, the government can get efficient and effective result in order to implement and manage the whole policy in the energy field.

\section{Analysis Preparation}

Evaluation conducted by using specific check list for ICS(Industrial Control System) basically. The checklist was created based on the NIST Special Publication 800-53 that include security guidance and recommended check list for ICS. The evaluation sheet is the same as the next and the answer to each item is classified Yes, No, Partial and N/A.

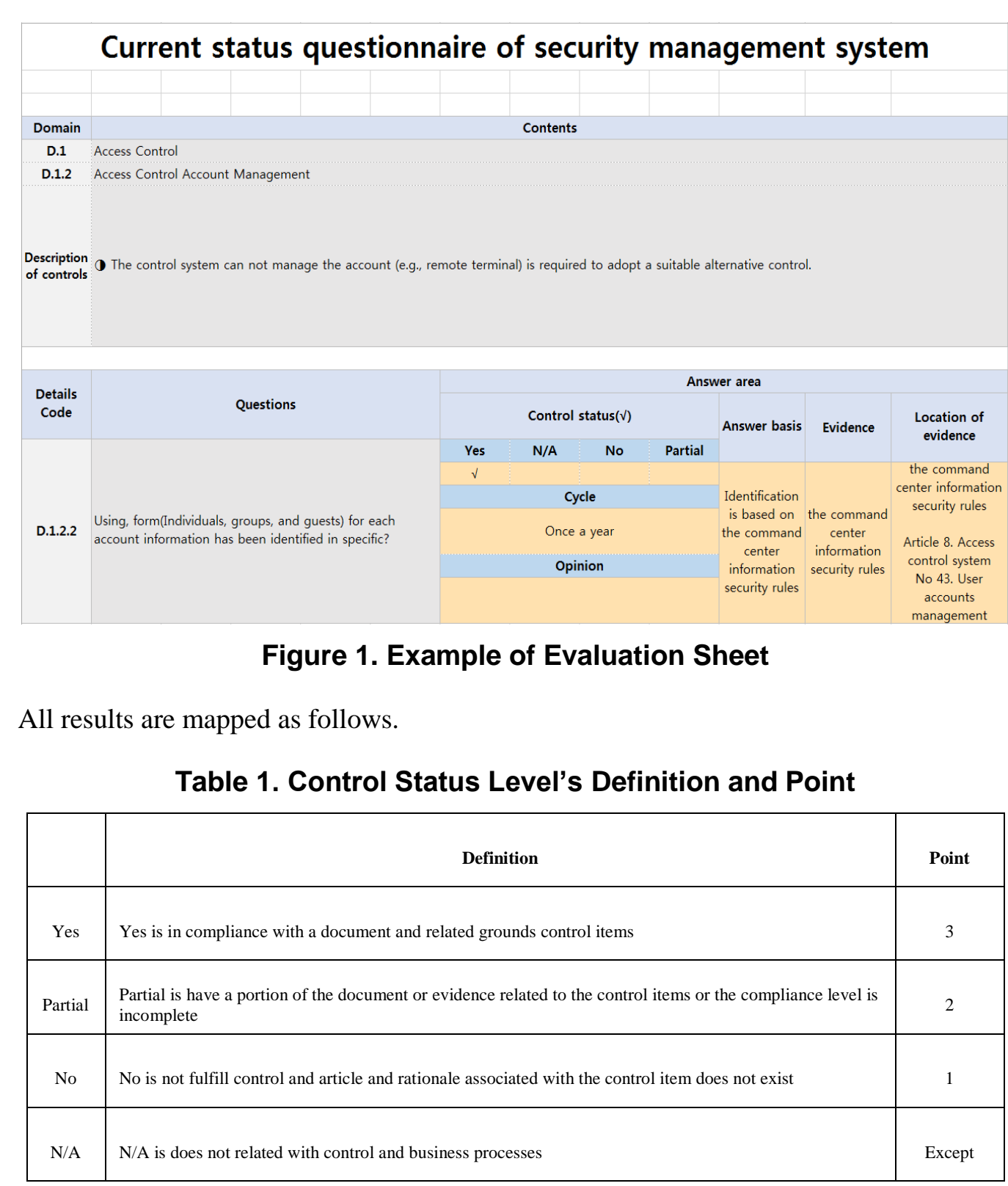


In addition, description of controls is added explanation for the detail situation of ICS for the answers and Answer basis, Evidence and Location of evidence are an item for reliability evaluation.

The check list configured main domain, Sub domain, and control. Total number of main domain is 14 domains and total number of sub domain is 90 domains. Total number of control is 186 pieces. Configure for main domain and Sub domain are as follows.

Table 2. Domain Name and Control Number

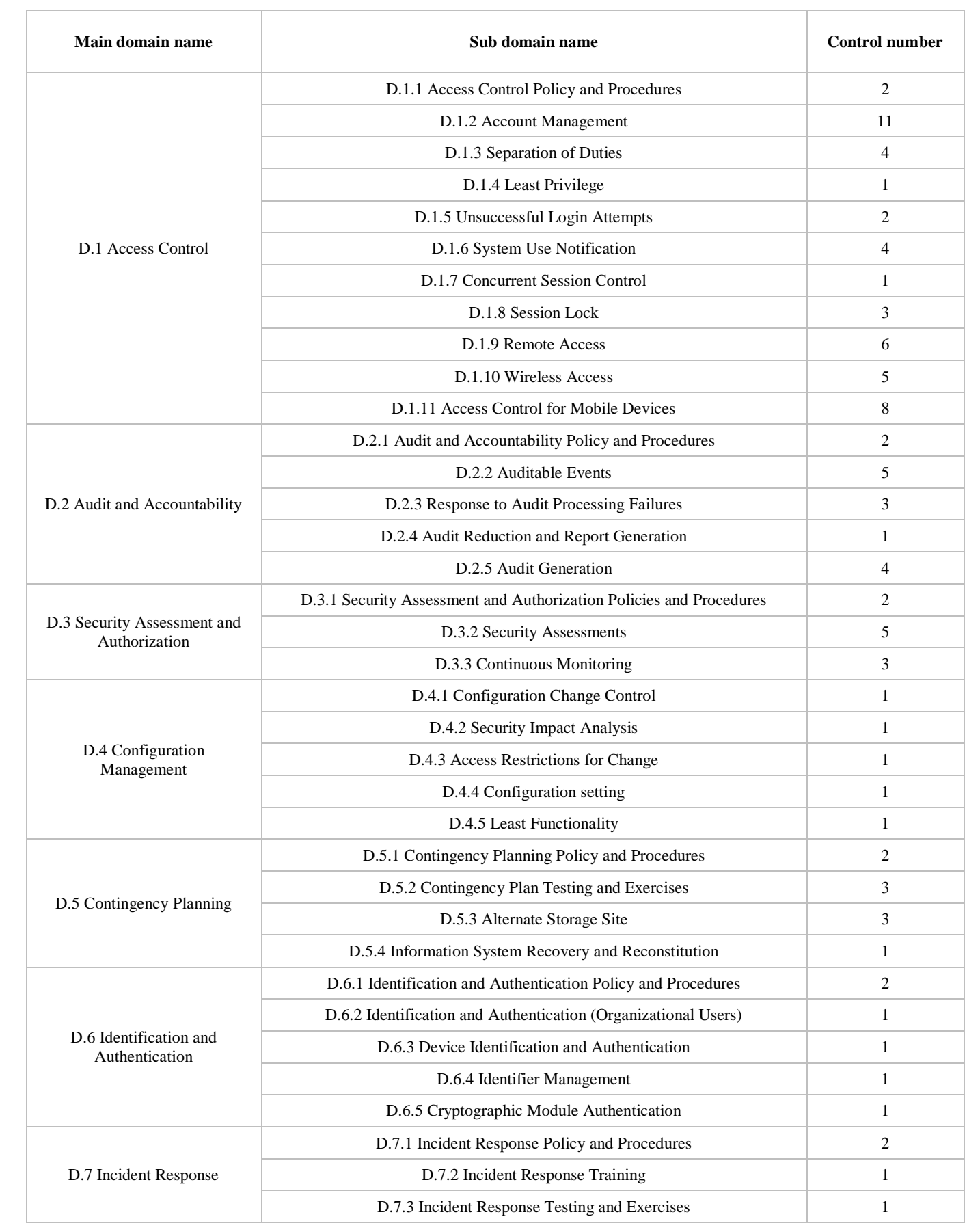




\begin{tabular}{|c|c|c|}
\hline & D.7.4 Incident Handling & 1 \\
\hline & D.7.5 Incident Response Plan & 1 \\
\hline \multirow{3}{*}{ D.8 Maintenance } & D.8.1 System Maintenance Policy and Procedures & 2 \\
\hline & D.8.2 Non-Local Maintenance & 6 \\
\hline & D.8.3 Maintenance Personnel & 1 \\
\hline \multirow{5}{*}{ D.9 Media Protection } & D.9.1 Media Protection Policy and Procedures & 2 \\
\hline & D.9.2 Media Access & 1 \\
\hline & D.9.3 Media Marking & 2 \\
\hline & D.9.4 Media Storage & 2 \\
\hline & D.9.5 Media Transport & 4 \\
\hline \multirow{9}{*}{$\begin{array}{l}\text { D.10 Physical and } \\
\text { Environmental Protection }\end{array}$} & D.10.1 Physical and Environmental Protection Policy and Procedures & 2 \\
\hline & D.10.2 Physical Access Authorizations & \\
\hline & D.10.3 Monitoring Physical Access & \\
\hline & & 1 \\
\hline & D.1 & 1 \\
\hline & D.10.7 Fir & 1 \\
\hline & & 1 \\
\hline & Damage Protection & 1 \\
\hline & Systenn Components & 1 \\
\hline \multirow{3}{*}{ D.11 Planning } & curity Plan & 1 \\
\hline & les of Behavior & 1 \\
\hline & vacy Impact Assessment & 1 \\
\hline \multirow{2}{*}{ D.12 Personnel Security } & nnel Transfer & 1 \\
\hline & D.12.2 Personnel Sanctions & 1 \\
\hline \multirow{6}{*}{$\begin{array}{c}\text { D.14 System and Services } \\
\text { Acquisition }\end{array}$} & D.13.1 Risk Assessment & 1 \\
\hline & D.13.2 Vulnerability Scanning & 6 \\
\hline & and Services Acquisition Policy and Procedures & 1 \\
\hline & D.14.2 User-Installed Software & 1 \\
\hline & D.14.3 Security Engineering Principles & 1 \\
\hline & D.14.4 Supply Chain Protection & 1 \\
\hline \multirow{13}{*}{$\begin{array}{c}\text { D.15 System and } \\
\text { Communications Protection }\end{array}$} & D.15.1 Application Partitioning & 1 \\
\hline & D.15.2 Security Function Isolation & 1 \\
\hline & D.15.3 Information in Shared Resources & 1 \\
\hline & D.15.4 Denial of Service Protection & 1 \\
\hline & D.15.5 Boundary Protection & 4 \\
\hline & D.15.6 Transmission Integrity & 1 \\
\hline & D.15.7 Transmission Confidentiality & 1 \\
\hline & D.15.8 Network Disconnect & 1 \\
\hline & D.15.9 Trusted Path & 1 \\
\hline & D.15.10 Cryptographic Key Establishment and Management & 1 \\
\hline & D.15.11 Use of Cryptography & 1 \\
\hline & D.15.12 Public Access Protections & 1 \\
\hline & D.15.13 Collaborative Computing Devices & 1 \\
\hline
\end{tabular}




\begin{tabular}{|c|c|c|}
\hline & D.15.14 Mobile Code & 2 \\
\hline & D.15.15 Voice Over Internet Protocol & 2 \\
\hline & D.15.16 Session Authenticity & 1 \\
\hline \multirow{3}{*}{$\begin{array}{l}\text { D.16 System and Information } \\
\text { Integrity }\end{array}$} & D.16.1 Flaw Remediation & 4 \\
\hline & D.16.2 Malicious Code Protection & 5 \\
\hline & D.16.3 Spam Protection & 2 \\
\hline \multirow{5}{*}{ D.17 Awareness and Training } & D.17.1 Security Awareness and Training Policy and Procedures & 2 \\
\hline & D.17.2 Security Awareness & 1 \\
\hline & D.17.3 Security Training & 1 \\
\hline & D.17.4 Security Training Records & 1 \\
\hline & & 186 \\
\hline
\end{tabular}

It is intended for developers and operation of energy management systems workers and Process Owner. This evaluation was conducted in the energy field of practice and in this paper, we analyze the thermal power field.

\section{Analysis of Common Security Factor for Energy Industry Group}

This paper will compare and analyze the 6 energy industry target groups (thermal, gas, nuclear, combined cycle, electricity, power exchange) through survey. And then this paper find the common ground of 6 energy industry group that will be proven by logic.

The step of proof is as follows.

First, it compare to survey result of 6 energy industry groups and then extract controls that all energy industry are observed.

Table 3. The Collection of Control that Every Energy Industry are Observed

\begin{tabular}{|c|c|c|c|c|c|c|c|c|c|}
\hline \multirow{2}{*}{ No } & \multirow{2}{*}{$\begin{array}{c}\text { Main domain } \\
\text { name }\end{array}$} & & \multirow{2}{*}{$\begin{array}{c}\text { Question } \\
\text { s code }\end{array}$} & \multicolumn{6}{|c|}{ Energy industry groups } \\
\hline & & & & $\begin{array}{c}\begin{array}{c}\text { Power } \\
\text { exchange }\end{array} \\
\end{array}$ & Electricity & Gas & $\begin{array}{c}\text { Combined } \\
\text { Cycle }\end{array}$ & Nuclear & Thermal \\
\hline 1 & & & 1.2 .2 & Yes & Yes & Yes & Yes & Yes & Yes \\
\hline 2 & & & 1.3 .4 & Yes & Yes & Yes & Yes & Yes & Yes \\
\hline 3 & & st Privilege & 1.4 .1 & Yes & Yes & Yes & Yes & Yes & Yes \\
\hline 4 & & ss & 9.2 .1 & Yes & Yes & Yes & Yes & Yes & Yes \\
\hline 5 & & rking & 9.3 .1 & Yes & Yes & Yes & Yes & Yes & Yes \\
\hline 6 & & & 9.3 .2 & Yes & Yes & Yes & Yes & Yes & Yes \\
\hline 7 & & Media Storage & 9.4 .1 & Yes & Yes & Yes & Yes & Yes & Yes \\
\hline 8 & & & 9.4 .2 & Yes & Yes & Yes & Yes & Yes & Yes \\
\hline & & Media & 9.5 .2 & Yes & Yes & Yes & Yes & Yes & Yes \\
\hline 10 & & & 9.5 .4 & Yes & Yes & Yes & Yes & Yes & Yes \\
\hline 11 & Physical and & $\begin{array}{c}\text { Physical } \\
\text { Access } \\
\text { Authorizations }\end{array}$ & 10.2 .1 & Yes & Yes & Yes & Yes & Yes & Yes \\
\hline 12 & $\begin{array}{c}\text { Environmental } \\
\text { Protection }\end{array}$ & Monitoring & 10.3 .1 & Yes & Yes & Yes & Yes & Yes & Yes \\
\hline 13 & & Physical Access & 10.3 .2 & Yes & Yes & Yes & Yes & Yes & Yes \\
\hline 14 & & Visitor Control & 10.4 .1 & Yes & Yes & Yes & Yes & Yes & Yes \\
\hline
\end{tabular}




\begin{tabular}{|c|c|c|c|c|c|c|c|c|c|}
\hline 15 & & $\begin{array}{c}\text { Emergency } \\
\text { Shutoff }\end{array}$ & 10.5 .1 & Yes & Yes & Yes & Yes & Yes & Yes \\
\hline 16 & & $\begin{array}{c}\text { Emergency } \\
\text { Lighting }\end{array}$ & 10.6.1 & Yes & Yes & Yes & Yes & Yes & Yes \\
\hline 17 & & Fire Protection & 10.7.1 & Yes & Yes & Yes & Yes & Yes & Yes \\
\hline 18 & & $\begin{array}{c}\text { Temperature } \\
\text { and Humidity } \\
\text { Controls }\end{array}$ & 10.8 .1 & Yes & Yes & Yes & Yes & Yes & Yes \\
\hline 19 & & $\begin{array}{l}\text { Water Damage } \\
\text { Protection }\end{array}$ & 10.9.1 & Yes & Yes & Yes & Yes & Yes & Yes \\
\hline 20 & & $\begin{array}{l}\text { Location of } \\
\text { Information } \\
\text { System } \\
\text { Components }\end{array}$ & 10.10 .1 & Yes & Yes & Yes & Yes & Yes & Yes \\
\hline 21 & \multirow{3}{*}{$\begin{array}{l}\text { System and } \\
\text { Communicatio } \\
\text { ns Protection }\end{array}$} & $\begin{array}{l}\text { Denial of } \\
\text { Service } \\
\text { Protection }\end{array}$ & 15.4.1 & Yes & Yes & Yes & Yes & Yes & Yes \\
\hline 22 & & \multirow{2}{*}{$\begin{array}{l}\text { Boundary } \\
\text { Protection }\end{array}$} & 15.5.1 & Yes & Yes & Yes & Yes & & \\
\hline 23 & & & 15.5.4 & Yes & Yes & $\mathrm{Yc}$ & Yes & & Yes \\
\hline
\end{tabular}

As the table above, the total number of main domains are 4 pieces, and sub domains are 23 pieces. These domains are common security factor for energy industry groups.

Second, it make a supposition as below through above result.

"Above 4 main domains and 23 sub domains are common security factor of 6 energy industry groups in total main domains andsub domains."

To prove this point, it distinguish remaining controlfom 4 main domains and 23 sub domains.

Table 4. The Number of Control for Every Group's Common Security Factor

\begin{tabular}{|c|c|c|c|c|}
\hline $\begin{array}{l}\text { Main domain } \\
\text { name }\end{array}$ & Sub domain name & $\begin{array}{l}\text { b domain control } \\
\text { number } \\
\text { (all question) }\end{array}$ & $\begin{array}{c}\text { Common control } \\
\text { number } \\
\text { (all energy industry } \\
\text { group) }\end{array}$ & Remain control number \\
\hline \multirow{3}{*}{ Access Control } & ccount Manageme & 10 & 1 & 9 \\
\hline & Separation of Duties & 4 & 1 & 3 \\
\hline & Least Privilege & 1 & 1 & 0 \\
\hline \multirow{4}{*}{ Media Protection } & Média Acees & 1 & 1 & 0 \\
\hline & Media Marking & 2 & 2 & 0 \\
\hline & Mediastorage & 2 & 2 & 0 \\
\hline & Media Transport & 4 & 2 & 2 \\
\hline \multirow{9}{*}{$\begin{array}{l}\text { Physical and } \\
\text { Environmental } \\
\text { Protection }\end{array}$} & Phlysical Access Authorizations & 2 & 1 & 1 \\
\hline & Monitoring Physical Access & 3 & 2 & 1 \\
\hline & Visitor Control & 1 & 1 & 0 \\
\hline & Emergency Shutoff & 1 & 1 & 0 \\
\hline & Emergency Lighting & 1 & 1 & 0 \\
\hline & Fire Protection & 1 & 1 & 0 \\
\hline & Temperature and Humidity Controls & 1 & 1 & 0 \\
\hline & Water Damage Protection & 1 & 1 & 0 \\
\hline & $\begin{array}{c}\text { Location of Information System } \\
\text { Components }\end{array}$ & 1 & 1 & 0 \\
\hline \multirow{2}{*}{$\begin{array}{c}\text { System and } \\
\text { Communications } \\
\text { Protection }\end{array}$} & Denial of Service Protection & 1 & 1 & 0 \\
\hline & Boundary Protection & 4 & 2 & 2 \\
\hline & & & 23 & \\
\hline
\end{tabular}

As the table above, the number of remaining control is 18 pieces on 23 sub domains.

Third, this paper analyze control that any 5 target groups perform well to prove supposition as follow. 
Table 5. The Number of Control for Almost all Group's Common Security Factor

\begin{tabular}{|c|c|c|c|c|}
\hline $\begin{array}{l}\text { Main domain } \\
\text { name }\end{array}$ & Sub domain name & $\begin{array}{c}\text { Remain control } \\
\text { number } \\
\text { (all energy } \\
\text { industry group) }\end{array}$ & $\begin{array}{c}\text { Common control } \\
\text { number } \\
(5+1 \text { energy industry } \\
\text { group) }\end{array}$ & $\begin{array}{c}\text { Remain Control } \\
\text { number } \\
(5+1 \text { energy industry } \\
\text { group) }\end{array}$ \\
\hline \multirow{6}{*}{ Access Control } & $\begin{array}{c}\text { Access Control Policy and } \\
\text { Procedures } \\
\end{array}$ & & 2 & \\
\hline & Wireless Access & & 1 & \\
\hline & Account Management & 9 & 6 & 3 \\
\hline & Separation of Duties & 3 & 3 & 0 \\
\hline & Unsuccessful Login Attempts & & 1 & \\
\hline & System Use Notification & & 1 & \\
\hline $\begin{array}{c}\text { Physical and } \\
\text { Environmental } \\
\text { Protection } \\
\end{array}$ & $\begin{array}{l}\text { Physical and Environmental } \\
\text { Protection Policy and Procedures }\end{array}$ & & 2 & \\
\hline \multirow{2}{*}{ Risk Assessment } & Risk Assessment & & 1 & \\
\hline & Vulnerability Scanning & & 4 & \\
\hline \multirow{3}{*}{$\begin{array}{c}\text { System and } \\
\text { Communications } \\
\text { Protection }\end{array}$} & Application Partitioning & & 1 & \\
\hline & Boundary Protection & 2 & & 1 \\
\hline & Trusted Path & & & \\
\hline \multirow{3}{*}{$\begin{array}{l}\text { System and } \\
\text { Information } \\
\text { Integrity }\end{array}$} & Flaw Remediation & & & \\
\hline & Malicious Code Protection & & & \\
\hline & Spam Protection & & 2 & \\
\hline $\begin{array}{l}\text { Configuration } \\
\text { Management }\end{array}$ & Security Impact Analysis & & & \\
\hline $\begin{array}{l}\text { Contingency } \\
\text { Planning } \\
\end{array}$ & $\begin{array}{l}\text { Information System Recovery and } \\
\text { Reconstitution } \\
\end{array}$ & & 1 & \\
\hline Maintenance & Non-Local Maintenance & & 1 & \\
\hline \multirow{2}{*}{ Media Protection } & $\begin{array}{c}\text { Media Protection Policy } \\
\text { Procedures }\end{array}$ & & 2 & \\
\hline & Media Transport & & 2 & 0 \\
\hline & & & 40 & \\
\hline
\end{tabular}

\section{Result of Analysis}

(a) The total number of control on survey is 186 pieces. Among them, the number of control and sub domain that every (6 groups) target groups perform well is 23 pieces and 18 pieces. And then control remain 163 pieces.

(b) In 163 pieces, the number of control that almost all(5 groups) target groups perform well is 40 pieces. Therefore, The above general probability is 24 percent on case that almost all(5 groups) target groups perform well.

(c) In 163 pieces, the number of control that included (a)'s 18 domain is 18 pieces.

Therefore, the more (c)'s 18 pieces include in (b)'s 40 pieces, the more Assumption may be true.

In conclusion, (c)'s 18 pieces include 12 pieces in (b)'s 40 pieces. If (c)'s 18 pieces is strongly affected, 4.3 pieces should include in (c)'s 18 pieces. In other words, the probability that (c)'s 18 pieces include 12 pieces in (b)'s 40 pieces is higher about 3 times than above general probability.

\section{Conclusion}

This paper presented the common security factor that is Account Management, Separation of Duties, Least Privilege, Media Access, Media Marking, Media Storage, Media Transport, 
Physical Access Authorizations, Monitoring Physical Access, Visitor Control, Emergency Shutoff, Emergency Lighting, Fire Protection, Temperature and Humidity Controls, Water Damage Protection, Location of Information System Components, Denial of Service Protection and Boundary Protection.

As above proof, the common security factor is not characteristic from only each specific energy field but common characteristic. And it could be preferentially managed important domain overall energy industry

To put it concretely, this paper is presented that Energy groups are generally manage the preferentially protection of external access, data flow, environment (temparature, humidity) parts.

Through the results of this paper, the government can get efficient and effective result in order to implement and manage the whole policy in the energy field.

\section{Acknowledgements}

This research was supported by the MKE(The Ministry of Knowledge Econoniy), Korea, under the ITRC(Information Technology Research Center) support program (NIPA-2013-H0301-13-3007) supervised by the NIPA(National IT Industry Promotion Agencr)

\section{References}

[1] National Institute of Standards and Technology "NIST SP 800-55", (2007) September.

[2] National Institute of Standards and Technology "NIST SP 800-82, (2011) June.

[3] National Institute of Standards and Technology NIST SP 800-53, (2009), August.

[4] International Organization for Standardization " ISO 27004 (2009).

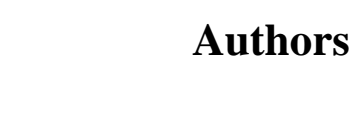

Sanghyun Park, is now a Master Course in Graduate School of Information Management and Security at Korea University since 2013.

Sangkyo Oh is now Master Course in Graduate School of Information Management and Security at Korea University since 2013.

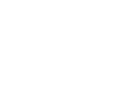

Kyungho Lee, received his Ph.D. degree from Korea University. He is now a Professor in Graduate School of Information Security and Security at Korea University, and leading the Risk management Laboratory in Korea University since 2012. He has a high level of theoretical principles as well as on-site experience. He was a former CISO in NAVER coporation, and now he takes as the CEO of SecuBase corporation. His research interests include information security management system(ISMS), risk management, information security consulting, privacy policy, and privacy impact assessment(PIA). 